\title{
START-UP OF HORIZONTAL ANAEROBIC REACTORS WITH SLUDGE BLANKET AND FIXED BED FOR WASTEWATER TREATMENT FROM COFFEE PROCESSING BY WET METHOD
}

\author{
ROBERTO A. DE OLIVEIRA ${ }^{1}$, NATANI M. N. BRUNO ${ }^{2}$
}

\begin{abstract}
In this study it was evaluated the start-up procedures of anaerobic treatment system with three horizontal anaerobic reactors (R1, R2 and R3), installed in series, with volume of $1.2 \mathrm{~L}$ each. R1 had sludge blanket, and R2 and R3 had half supporter of bamboo and coconut fiber, respectively. As an affluent, it was synthesized wastewater from mechanical pulping of the coffee fruit by wet method, with a mean value of total chemical oxygen demand (CODtotal) of $16,003 \mathrm{mg} \mathrm{L}^{-1}$. The hydraulic retention time (HRT) in each reactor was $30 \mathrm{~h}$. The volumetric organic loading (VOL) applied in R1 varied from 8.9 to $25.0 \mathrm{~g}$ of CODtotal $(\mathrm{L} \mathrm{d})^{-1}$. The mean removal efficiencies of CODtotal varied from 43 to $97 \%$ in the treatment system (R1+R2+R3), stabilizing above $80 \%$ after 30 days of operation. The mean content of methane in the biogas were of 70 to $76 \%$, the mean volumetric production was $1.7 \mathrm{~L} \mathrm{CH}_{4}(\mathrm{~L} \text { reactor } \mathrm{d})^{-1}$ in the system, and the higher conversions were around at $0.20 \mathrm{~L} \mathrm{CH}_{4}\left(\mathrm{~g} \mathrm{COD}_{\text {removed }}\right)^{-1}$ in $\mathrm{R} 1$ and $\mathrm{R} 2$. The mean values of $\mathrm{pH}$ in the effluents ranged from 6.8 to 8.3 and the mean values of total volatile acids remained below $200 \mathrm{mg} \mathrm{L}^{-1}$ in the effluent of R3. The concentrations of total phenols of the affluent ranged from 45 to $278 \mathrm{mg} \mathrm{L}^{-1}$, and the mean removal efficiency was of 52\%. The start-up of the anaerobic treatment system occurred after 30 days of operation as a result of inoculation with anaerobic sludge with active microbiota.
\end{abstract}

KEYWORDS: volumetric organic loading, bamboo, methane, phenols, reactors in series.

\section{PARTIDA DE REATORES ANAERÓBIOS HORIZONTAIS COM MANTA DE LODO E DE LEITO FIXO PARA TRATAMENTO DE ÁGUAS RESIDUÁRIAS DO BENEFICIAMENTO DE FRUTOS DO CAFEEIRO POR VIA ÚMIDA}

RESUMO: Foram avaliados os procedimentos de partida de sistema de tratamento com três reatores anaeróbios horizontais (R1, R2 e R3), instalados em série, com volume de 1,2 L cada. O R1 com manta de lodo e o R2 e R3 através de suporte de bambu e fibra de coco, respectivamente. Como afluente, foram sintetizadas águas residuárias do despolpamento mecânico dos frutos do cafeeiro por via úmida, com valor médio de demanda química de oxigênio total (DQOtotal) de $16.003 \mathrm{mg} \mathrm{L}^{-1}$. O tempo de detenção hidráulica (TDH) em cada reator foi de $30 \mathrm{~h}$. As cargas orgânicas volumétricas (COV) no R1 foram de 8,9 a 25,0 g DQOtotal ( $\mathrm{L} \mathrm{d})^{-1}$. As eficiências de remoção de DQOtotal variaram de 43 a $97 \%$ no sistema de tratamento (R1+R2+R3), estabilizando acima de $80 \%$ após 30 dias de operação. Os teores médios de metano no biogás foram de 70 a $76 \%$, a produção volumétrica média de $1,7 \mathrm{~L} \mathrm{CH}_{4}(\mathrm{~L} \text { reator d })^{-1}$ no sistema, e as conversões mais altas, de $0,20 \mathrm{~L} \mathrm{CH}_{4}$ (g DQOremovida) ${ }^{-1}$, ocorreram no R1 e R2. Os valores médios de $\mathrm{pH}$ nos efluentes foram de 6,8 a 8,3 e de ácidos voláteis totais permaneceram abaixo de $200 \mathrm{mg} \mathrm{L}^{-1}$ no efluente do $\mathrm{R} 3$. As concentrações de fenóis totais do afluente variaram de 45 a $278 \mathrm{mg} \mathrm{L}^{-1}$, e a eficiência média de remoção foi de 52\%. A partida do sistema de tratamento ocorreu após $30 \mathrm{~d}$, em virtude da inoculação com lodo anaeróbio com microbiota ativa.

PALAVRAS-CHAVE: carga orgânica volumétrica, bambu, metano, fenóis, reatores em série.

\footnotetext{
${ }^{1}$ Eng ${ }^{0}$ Agrônomo e Tecnólogo em Construção Civil, Mestre em Agronomia e Doutor em Hidráulica e Saneamento, Professor da Faculdade de Ciências Agrárias e Veterinárias, Universidade Estadual Paulista, Câmpus de Jaboticabal, Departamento de Engenharia Rural, fone (0XX16) 3209.2637, raoder@fcav.unesp.br.

${ }^{2}$ Química, Mestre em Microbiologia Agropecuária pela Faculdade de Ciências Agrárias e Veterinárias, UNESP, Universidade Estadual Paulista, Câmpus de Jaboticabal. 


\section{INTRODUCTION}

The coffee production is one of the major activities in Brazil, for its participation in the socioeconomic context as well as the generation of jobs. According to CONAB (2012), the estimated national production of processed coffee beans for the harvest of 2012 will be 50.45 million bags of $60 \mathrm{~kg}$.

Coffee is one of the few agricultural products whose value grows considerably with improved quality. Thus, the economic viability of coffee production is strongly associated with correct techniques and rational management of the processing system, due to the direct influence on the quality of grain and drinking coffee. The coffee fruit can be processed by dry or wet methods. In wet method, the coffee cherries are washed and peeled, and in some cases the mucilage is removed. The wet method is particularly suitable to the Coffea arábica species, and it is responsible for about one third of the world's coffee production. Although Brazil is known as a producer of coffee beans obtained by dry method, form of production which correspond to approximately $90 \%$ of national production (LEITE \& SILVA, 2000), the wet method has become more and more attractive, because, besides providing grain yield of high quality, with good prices in the market, it reduces the cost of drying of grains, and therefore it has accentuated increase in Brazil.

However, wet processing consumes large volumes of water that now contain mucilage and pulp, fruit components of great pollutant power to the aquatic environment. In the processing by traditional wet method, four tons of water is necessary to produce one ton of processed grain. In the producing regions, the dumping of such waste has become a major environmental problem, with demand for simplified systems of waste management with low cost of implementation and operation (MATOS \& LO MONACO, 2003).

With the improvement, in recent years, of the anaerobic technology of treatment of organic effluents, new configurations of reactors have been proposed, especially the high rate reactors, which are characterized by the existence of favorable conditions for the immobilization of active biomass responsible for biological degradation of organic matter and toxic waste.

Some settings of high rate anaerobic reactors were investigated for the treatment of wastewater from coffee fruit by the wet method. The most evaluated was the upflow anaerobic reactor with sludge blanket (UASB), at one stage, two stages and hybrid (with fixed bed at the top), followed by anaerobic reactors of fixed bed with ascending and descending flow, as described in Table 1.

In these reactors, it was used hydraulic retention times (HRT) of 6 to $144 \mathrm{~h}$, volumetric organic loading (VOL) from 0.14 to $28.46 \mathrm{~g} \mathrm{COD}(\mathrm{L} \mathrm{d})^{-1}$, affluents with COD from 235 to $23,040 \mathrm{mg} \mathrm{L}^{-1}$ and total phenol concentrations from 12 to $388 \mathrm{mg} \mathrm{L}^{-1}$. It was obtained efficiencies of COD removal from 33 to $98 \%$ and of phenols from -3 to $90 \%$, with biogas production from 0.06 to $5.09 \mathrm{~L}$ ( $\left.\mathrm{L}_{\text {reactor }}\right)^{-1}$ and from 0.26 to $0,43 \mathrm{~L}$ ( $\mathrm{g} \mathrm{COD}_{\text {removed }}$ ), methane contents from 28 to $89 \%$, and conversions from 0.13 to $0.26 \mathrm{~L} \mathrm{CH} 4$ (g COD removed) (Table 1). 
TABLE 1. Research papers with anaerobic treatment of coffee wastewater from wet method: authors, type of reactor, hydraulic retention time (HRT), volumetric organic loading (VOL), chemical oxygen demand (COD) and total phenols (TP) of affluent, total volatile acids (TVA) of effluent, removal efficiencies of COD and TP, and biogas quality and production.

\begin{tabular}{|c|c|c|c|c|c|c|c|c|c|}
\hline \multirow[t]{3}{*}{ Authors } & \multirow{3}{*}{$\begin{array}{l}\text { Anaerobic } \\
\text { Reactor }\end{array}$} & \multirow{3}{*}{$\begin{array}{l}\text { HRT } \\
(\mathrm{h}) \\
\end{array}$} & \multirow{3}{*}{$\begin{array}{l}\text { VOL } \\
\text { (a) } \\
\end{array}$} & \multicolumn{2}{|c|}{ Affluent } & \multirow{3}{*}{$\begin{array}{l}\text { Effl. } \\
\text { TVA } \\
\text { (b) }\end{array}$} & \multicolumn{2}{|c|}{ Rem. Effic. } & \multirow{3}{*}{$\begin{array}{l}\text { Biogas: } \\
\text { (c) quality } \\
\text { (d) production } \\
\end{array}$} \\
\hline & & & & COD & $\mathrm{TP}$ & & $\mathrm{COD}$ & $\mathrm{TP}$ & \\
\hline & & & & \multicolumn{2}{|c|}{$\left(\mathrm{mg} \mathrm{L}^{-1}\right)$} & & \multicolumn{2}{|l|}{$(\%)$} & \\
\hline $\begin{array}{l}\text { BORGES et al. } \\
(2009)\end{array}$ & $\begin{array}{l}\text { Horizontal } \\
\text { Fixed bed } \\
(100 \mathrm{~L})\end{array}$ & 11.5 & 2.66 & 1084 & 13 & 376 & 49 & - & - \\
\hline YSSPERT (1984) (e) & $\begin{array}{l}\text { UASB (23 and } \\
270 \text { L) }\end{array}$ & 6 & 15 & - & - & - & 80 to 90 & - & - \\
\hline OSORIO (1994) (e) & UASB & 72 to 29 & $\begin{array}{c}0.15 \text { to } \\
2.20\end{array}$ & - & - & - & 55 to 80 & - & - \\
\hline $\begin{array}{l}\text { VINAS et al. (1998) } \\
\text { (e) }\end{array}$ & UASB (20 L) & - & $>15$ & - & - & - & 75 to 80 & - & (d1)5.09 \\
\hline $\begin{array}{l}\text { SILVA \& CAMPOS } \\
(2005)\end{array}$ & UASB (11.7 L) & 69 & 0.59 & 3250 & - & - & 78 & - & - \\
\hline $\begin{array}{l}\text { PRADO \& } \\
\text { CAMPOS (2008), } \\
\text { PRADO et al. } \\
(2010)\end{array}$ & UASB (12.54 L) & $\begin{array}{l}69.67 \text { to } \\
8.04\end{array}$ & $\begin{array}{l}0.14 \text { to } \\
20.29\end{array}$ & $\begin{array}{l}235 \text { to } \\
7064\end{array}$ & $\begin{array}{c}30 \text { to } \\
388\end{array}$ & 28 to 192 & 293 to 33 & $\begin{array}{c}-3 \\
\text { to } 70\end{array}$ & $\begin{array}{l}\text { (c) } 49 \text { to } 68 \% \\
\text { (d1) } 0.06 \text { to } \\
1.56\end{array}$ \\
\hline BRUNO \& & UASB (two & 96148 & 5.83 .6 & 23040 & 8097 & 1840 & 66 & 72 & (c) 69,88 and 89 \\
\hline OLIVEIRA (2008) & $\begin{array}{l}\text { stages) (20 and } \\
10 \mathrm{~L})\end{array}$ & 124 & 3.0 & $\begin{array}{l}21950 \\
15440\end{array}$ & 90 & $\begin{array}{l}85 \\
47\end{array}$ & $\begin{array}{l}98 \\
96\end{array}$ & $\begin{array}{l}90 \\
86\end{array}$ & $\begin{array}{c}\text { (d2) } 0.29 ; 0.48 \\
\text { and } 0.45 \\
\text { (d3) } 0.13 ; 0.15 \\
\text { and } 0.19\end{array}$ \\
\hline $\begin{array}{l}\text { BELLO-MENDOZA } \\
\text { \& CASTILLO- } \\
\text { RIVERA (1998) }\end{array}$ & $\begin{array}{l}\text { UASB hybrid } \\
(10,500 \mathrm{~L})\end{array}$ & 22 & 1.89 & 2480 & - & - & 77 & - & - \\
\hline $\begin{array}{l}\text { SELVAMURUGAN } \\
\text { et al. (2010a and b) }\end{array}$ & $\begin{array}{l}\text { UASB hybrid } \\
(19.25 \mathrm{~L})\end{array}$ & $\begin{array}{c}24 \\
18 \\
12 \\
6\end{array}$ & $\begin{array}{c}7.01 \\
9.55 \\
14.23 \\
28.46\end{array}$ & $\begin{array}{c}6420 \text { to } \\
8480\end{array}$ & - & - & $\begin{array}{l}70 \\
61 \\
59 \\
54\end{array}$ & - & $\begin{array}{c}\text { (d3) } 0.173 \\
0.261 \\
0.232 \\
0.133 \\
\text { (c) } 50 \text { to } 62 \%\end{array}$ \\
\hline $\begin{array}{l}\text { PORRES \& } \\
\text { CALZADA (1990) (e) }\end{array}$ & $\begin{array}{l}\text { Fixed bed } \\
\text { ascending flow }\end{array}$ & 53 & 2.2 & - & - & - & 55 & - & (d1) 0.34 \\
\hline WASSER (1991) (e) & $\begin{array}{l}\text { Fixed bed } \\
\text { ascending flow }\end{array}$ & 122 & 1.08 & - & - & - & 80 & - & - \\
\hline OSORIO (1994) (e) & $\begin{array}{l}\text { Fixed bed } \\
\text { ascending flow }\end{array}$ & 20 to 10 & $\begin{array}{c}0.43 \text { to } \\
3.74\end{array}$ & - & - & - & 44 to 88 & - & - \\
\hline LUIZ (2007) & Fixed bed & 37.9 to & 0.81 to & 9782401 & 13 to & 160 to & 80 to 42 & 68 to & - \\
\hline $\begin{array}{l}\text { FIA et al. (2010a and } \\
\text { b) }\end{array}$ & $\begin{array}{l}\text { ascending flow } \\
(139.5 \mathrm{~L})\end{array}$ & 25.4 & 4.41 & 4545 & 43 & 1083 & & 36 & \\
\hline $\begin{array}{l}\text { FIA et al. (2010c and } \\
\text { d) }\end{array}$ & $\begin{array}{l}\text { Fixed bed } \\
\text { descending flow } \\
(139.5 \mathrm{~L})\end{array}$ & $\begin{array}{l}10.2 \\
10.4 \\
10.3 \\
\end{array}$ & $\begin{array}{r}1.91 \\
3.66 \\
4.89 \\
\end{array}$ & $\begin{array}{l}1856 \\
2246 \\
2835\end{array}$ & $\begin{array}{c}1214 \\
18\end{array}$ & $\begin{array}{l}650 \text { to } \\
800\end{array}$ & $\begin{array}{c}60.033 .6 \\
33.9\end{array}$ & $\begin{array}{c}4130 \\
35\end{array}$ & - \\
\hline
\end{tabular}

Despite the wide range of variation of these results, it is observed that with the application of high rate anaerobic reactors, it is possible to choose operating conditions to obtain removal efficiencies of COD above $80 \%$, biogas production with methane contents above $60 \%$ and conversions of up to $0.26 \mathrm{~L} \mathrm{CH}_{4}$ ( $\mathrm{g} \mathrm{COD}_{\text {removed }}$ ), indicating the feasibility of anaerobic treatment of wastewater from coffee by wet method.

The horizontal anaerobic fixed bed reactors (HAFBR) are a new generation of high rate biological reactors, where it is possible to maintain a high concentration of biomass immobilized on 
the support, good hydrodynamic characteristics and HRT relatively short for high VOL (ZAIAT et al., 1994; BENIS et al., 2009).

BORGES et al. (2009) evaluated the start-up of HAFBR for 36 days, with low HRT and VOL, of $11.5 \mathrm{~h}$ and $2.66 \mathrm{~g}$ COD $(\mathrm{L} \mathrm{d})^{-1}$, respectively, and achieved mean removal efficiency of COD of $49 \%$ (Table 1). AMORIM et al. (2005) concluded that there is a need for studies to determine the application limits of VOL for better utilization of useful volume of HAFBR, making it more economical. The half supporter contributes to the increase in the solid retention time, favoring the methanogenic population and, thus, increases the capacity of the horizontal reactor to resist organic shocks, changes in the characteristics of the substrate, and the presence of toxic compounds, but may also contribute to clogging of the reactor due to excessive retention of suspended solids (RODGERS et al., 2008). To prevent clogging of the fixed bed, the horizontal anaerobic reactor can be used only with sludge blanket at one stage (BARBOZA, 2002 and SILVA et al., 2008) or in facilities in series.

SANTOS \& OLIVEIRA (2011) used four horizontal anaerobic reactors installed in series, the first with sludge blanket followed by three of fixed bed with half supporter of bamboo, plastic, and bushing rings, respectively, to treat swine wastewater. They applied VOL from 53 to $61 \mathrm{~g}$ COD $(\mathrm{L} \mathrm{d})^{-1}$ with HRT of 12 and $10 \mathrm{~h}$ in the first reactor, and obtained mean removal efficiencies of COD of 96 and $99 \%$, and TSS of 96 and $95 \%$, in all the four reactors, with methane production up to $0.52 \mathrm{~L} \mathrm{CH}_{4}(\mathrm{~L} \text { reactor } \mathrm{d})^{-1}$. Thus, for some situations, such as farms, where there are usually severe limitations of land area and there is need for soil conservation for agricultural production, the ease of installation and smaller requirements of area and of structural complexity of construction may also set up as advantages for the use of horizontal anaerobic reactors.

Moreover, a better understanding of the processes triggered in anaerobic treatment systems, when operated successfully using alternative support materials, such as bamboo (COLIN et al., 2007, and SANTOS \& OLIVEIRA, 2011) and other vegetable, could be an important alternative treatment of wastewater from processing coffee fruits, in order for this technology to be easily accessible to producers.

Thus, in this study it was evaluated the start-up of three horizontal anaerobic reactors installed in series, the first had sludge blanket and the next two had fixed bed of bamboo and coconut fiber, for the treatment of wastewater from the processing coffee fruits by wet method, with HRT of $30 \mathrm{~h}$ in each reactor and VOL from 8.9 to $25.0 \mathrm{~g} \mathrm{COD}_{\text {total }}(\mathrm{L} \mathrm{d})^{-1}$ in the first reactor.

\section{MATERIAL AND METHODS}

The study was conducted at the Department of Agricultural Engineering, of the College of Agriculture and Veterinary Sciences, of the Universidade Estadual Paulista - UNESP (São Paulo State University), Jaboticabal campus, whose geographical coordinates are: $21^{\circ} 15$ '22" South latitude, $48^{\circ} 18^{\prime} 58^{\prime}$ " West longitude and $575 \mathrm{~m}$ of altitude. The climate, according to Köeppen's classification, is Cwa (humid subtropical, dry in winter and rainy in summer), with mean annual rainfall of $1,300 \mathrm{~mm}$ and mean annual temperature of $21^{\circ} \mathrm{C}$ (UNESP, 2010).

The experimental unit consisted of feed and storage tank of the affluent, diaphragm metering pump, a horizontal anaerobic sludge blanket reactor (HASBR - R1) and two horizontal anaerobic fixed bed reactors (HAFBR - R2 and R3) installed in series (Figure 1). The reactors were built with PVC pipes and fittings, $80 \mathrm{~cm}$ long and $4.5 \mathrm{~cm}$ in diameter, with a total volume of $1.2 \mathrm{~L}$ each. The second reactor (R2) was filled with bamboo rings of $2 \mathrm{~cm}$ length and $1 \mathrm{~cm}$ in diameter, and the third reactor (R3) was filled with coconut fibers, chopped into parallelepipeds of $2 \times 1 \times 1 \mathrm{~cm}$, used as half supporter for the immobilization of microbial biomass. The first reactor with sludge blanket was used to prevent possible clogging, due to higher VOL applied. Following, the bamboo rings were placed in the R2, to obtain the benefits of immobilized biomass, and because it is a supporter with pore size larger than coconut fibers. 
For monitoring and storage of biogas production, it was installed plastic gasometers in R1, R2 and R3 (Figure 1). In each reactor, it was applied hydraulic retention time of $30 \mathrm{~h}$, completing $90 \mathrm{~h}$ in the set composed of the three reactors installed in series $(\mathrm{R} 1+\mathrm{R} 2+\mathrm{R} 3)$.

The affluent used for continuous feeding of R1 was prepared weekly by adding 3 liters of water to 1 liter of fruits of coffee (Arábica) beans, which remained immersed for $24 \mathrm{~h}$.

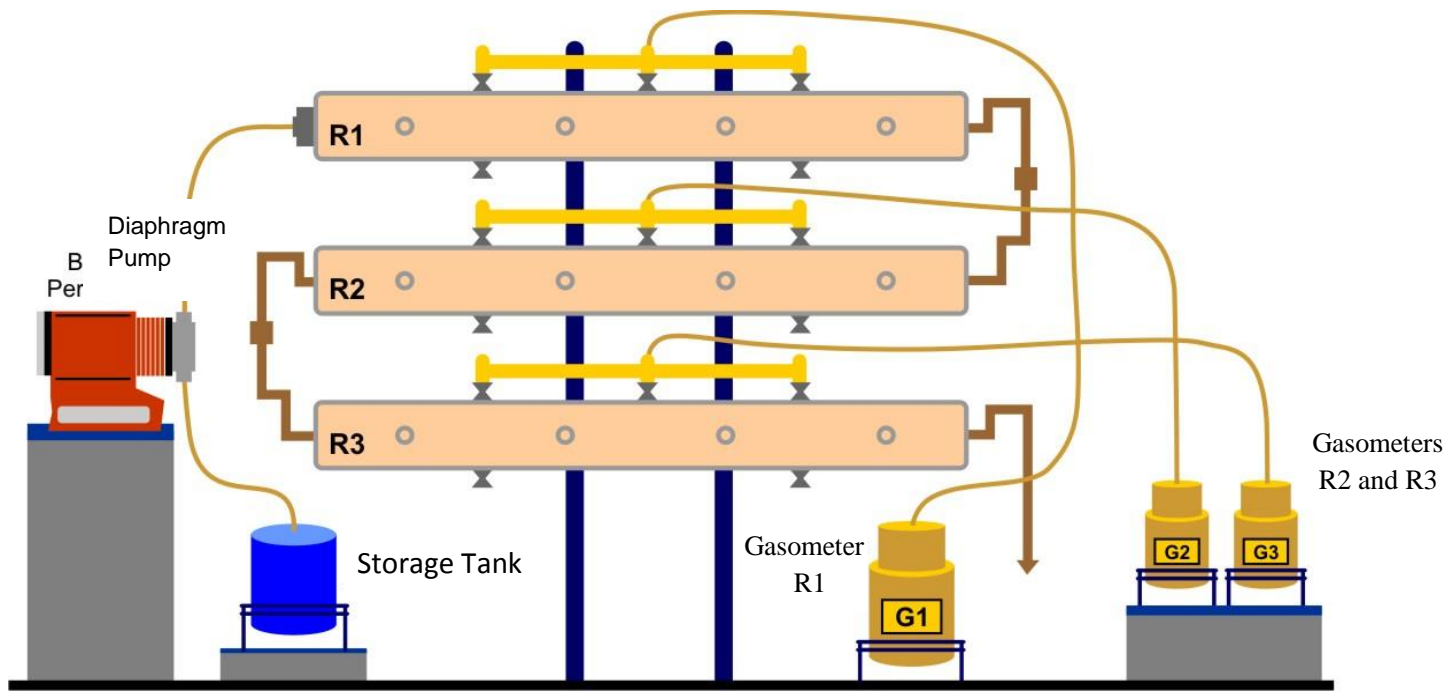

FIGURE 1. Experimental unit composed by horizontal anaerobic sludge blanket reactor (HASBR R1) and horizontal anaerobic fixed bed reactors (HAFBR), filled with bamboo rings (R2) and coconut fiber cubes (R3), gasometers (G) and diaphragm metering pump.

Then the coffee beans were rubbed and peeled by hand and kept in immersion for one more hour, thereby obtaining the wastewater with similar characteristics to the coffee pulping by the wet method held mechanically in producing properties, as was also verified by PRADO \& CAMPOS (2008). The $\mathrm{COD}_{\text {total }}$ of synthetic wastewater obtained was $16,000 \mathrm{mg} \mathrm{L}^{-1}$, and according to MATOS \& LO MONACO (2003), in the properties wastewater is produced with COD $_{\text {total }}$ ranging from 1,520 to $29,500 \mathrm{mg} \mathrm{L}^{-1}$. After this procedure, the wastewater was sieved (sieve with nylon square mesh of $1.5 \times 1.5 \mathrm{~mm}$ ), in order to separate the coarse solids, such as hulls and pieces of coffee beans, thus avoiding clogging of the pump line suction, and stored under freezing. The wastewater was defrosted and adequate to room temperature before use. It was also neutralized with lime with NP (Neutralization Power) and RPTN (Relative Power of Total Neutralization) of 99 and $83 \%$ in order to obtain affluent $\mathrm{pH}$ around 7.0 and thus be placed in the storage tank. The R2 was continuously fed by gravity with the effluent of R1, and the R3 was fed with R2 effluent.

Considering that, normally, there is little availability of sludge suitable for the start-up of high rate anaerobic reactors in conditions of real scale, especially in rural areas; it was adopted the inoculation strategy only for the first reactor filled with $25 \%$ volume. Thus, it was added to the first reactor (R1) $300 \mathrm{~mL}$ of flocculent sludge with some granules obtained from UASB reactor treating swine wastewater with total solids concentration of $56.8 \mathrm{~g} \mathrm{~L}^{-1}$.

To characterize the start-up, the reactors R1, R2 and R3 were continuously monitored for 130 days.

It was determined in the composite samples collected in the feed tank (affluent) and in the sampling taps on the output of the effluent from $\mathrm{R} 1, \mathrm{R} 2$ and $\mathrm{R} 3$ : $\mathrm{pH}$, total alkalinity (TA), total (TSS) and volatile (VSS) suspended solids; total $\left(\mathrm{COD}_{\text {total }}\right)$ and dissolved $\left(\mathrm{COD}_{\text {diss }}\right)$ chemical oxygen demand twice a week, according to APHA, AWWA, WPCF (2005). The concentrations of total volatile acids (TVA) were also determined twice a week, using methods described by DILALLO \& ALBERTSON (1961). The volume of biogas produced was determined daily by measuring the gasometers, as described by SANTOS \& OLIVEIRA (2011). The biogas composition was analyzed weekly by gas chromatography, as described by APHA, AWWA, WPCF 
(2005). The concentration of total phenols (TP) was determined once a week, according to the Folin-Ciocalteu method (1977) quoted by SHAHID \& NACZK (1995).

\section{RESULTS AND DISCUSSION}

The first reactor was fed with wastewater from the processing of synthetic coffee cherries, with mean values of TSS of $1,216 \mathrm{mg} \mathrm{L}^{-1}, \mathrm{COD}_{\text {total }}$ of $16,003 \mathrm{mg} \mathrm{L}^{-1}$ and $\mathrm{COD}_{\text {diss }}$ of $14,176 \mathrm{mg} \mathrm{L}^{-1}$, confirming the predominance of dissolved organic solids (Table 2). These mean values were similar to those obtained for wastewater from washing and pulping coffee (Arábica and Conilon) on farms, which, according to MATOS \& LO MONACO (2003), are between 1,520 and 29,500 mg L ${ }^{-1}$ and 380 and $6,200 \mathrm{mg} \mathrm{L}^{-1}$ for COD and TSS, respectively.

TABLE 2. Mean values and coefficient of variation (C.V. \%) of total and dissolved chemical oxygen demand (CODtotal and CODdiss in $\mathrm{mg} \mathrm{L}^{-1}$ ), total suspended solids (TSS in $\mathrm{mg} \mathrm{L}^{-1}$ ), total phenols (TP in mg L $\mathrm{L}^{-1}$ ), $\mathrm{pH}$, total alkalinity (TA in $\mathrm{mg} \mathrm{L}^{-1}$ of $\mathrm{CaCO}_{3}$ ), total volatile acids (TVA in $\mathrm{mg} \mathrm{L}^{-1}$ of $\mathrm{CH}_{3} \mathrm{COOH}$ ) and volumetric organic loading (VOL in $\mathrm{g}$ CODtotal $\left.(\mathrm{L} \mathrm{d})^{-1}\right)$, obtained during the start-up of the horizontal anaerobic reactors $\mathrm{R} 1$, $\mathrm{R} 2$ and $\mathrm{R} 3$, installed in series.

\begin{tabular}{ccccccccc}
\hline Parameter & Affluent & C.V. & R1 & C.V. & R2 & C.V. & R3 & C.V. \\
\hline VOL & - & - & 12.8 & 29 & 4.9 & 22 & 3.3 & 43 \\
\hline COD $_{\text {total }}$ & 16003 & 29 & 6130 & 32 & 4068 & 43 & 2975 & 64 \\
COD $_{\text {diss }}$ & 14176 & 31 & 5826 & 36 & 3688 & 33 & 2708 & 69 \\
TSS & 1216 & 30 & 538 & 45 & 333 & 43 & 261 & 43 \\
TP & 105 & 53 & 47 & 37 & 38 & 39 & 44 & 34 \\
pH & 6.3 & 3 & 7.5 & 4 & 7.8 & 5 & 7.9 & 3 \\
TA & 1494 & 30 & 2052 & 18 & 2799 & 8 & 2493 & 22 \\
TVA & 2205 & 16 & 1269 & 34 & 376 & 36 & 168 & 66 \\
\hline
\end{tabular}

The values of $\mathrm{COD}_{\text {total }}$ in the affluent and effluent of R1, R2 and R3 during the start-up are shown in Figure 2. It was observed variations in the $\mathrm{COD}_{\text {total }}$ of the affluent from 11,000 to $32,230 \mathrm{mg} \mathrm{L}^{-1}$ which were reflected in the values of $\mathrm{COD}_{\text {total }}$ of effluents of R1, R2 and R3 until the 54 days of operation.

Thereafter, values of $\mathrm{COD}_{\text {total }}$ of the effluent of R1 and R2 decreased until 80 days of operation, when they suffered a shock of organic loading, which has been assimilated without pronounced changes in effluent quality. Until 130 days of operation, it was observed, in the affluents and effluents, stable values of $\mathrm{COD}_{\text {total }}$.

From 89 to 100 days of operation, in the effluent of R3, values increased, ranging from 2,715

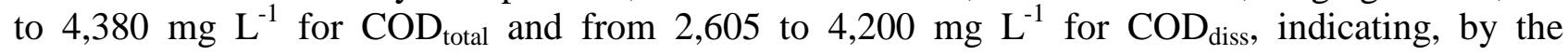
predominance of dissolved organic matter, solubilization of organic fractions less stable of the organic half supporter (coconut fibers), along with the start of entrainment of solids from the accumulated sludge, which is stabilized until 130 days of operation.

Even with the fluctuations of $\mathrm{COD}_{\text {total }}$ and $\mathrm{COD}_{\text {diss }}$ of the affluent, mean values were decreasing in the effluents of $\mathrm{R} 2$ and $\mathrm{R} 3$, of 2,975 and $2,708 \mathrm{mg} \mathrm{L}^{-1}$ (Table 2), respectively, demonstrating the ability of the treatment system to accommodate the high VOL and its variations, maintaining the quality of the effluent with high removal of suspended and dissolved organic matter. 


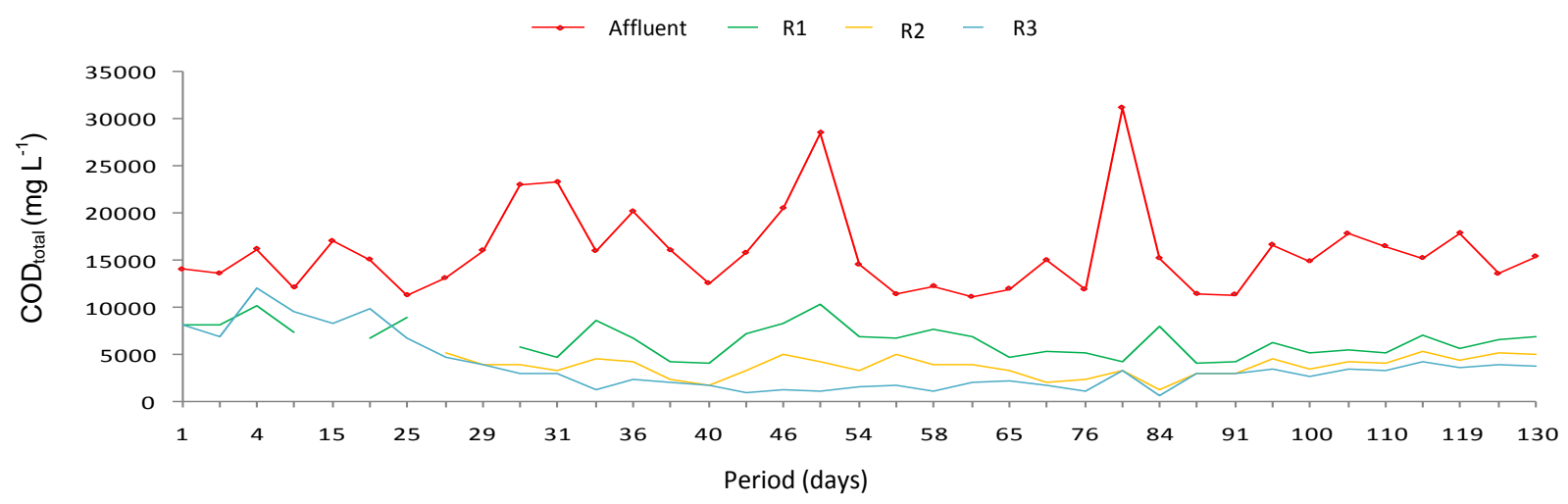

FIGURE 2. Total chemical oxygen demand $\left(\mathrm{COD}_{\text {total }}\right)$ in the affluent and effluent of the horizontal anaerobic reactors with sludge blanket (R1) and fixed bed (R2 and R3), installed in series, during the start-up.

The removal of $\mathrm{COD}_{\text {total }}$ in the set of reactors $(\mathrm{R} 1+\mathrm{R} 2+\mathrm{R} 3)$ increased continuously throughout the 30 days of operation, reaching $85 \%$ of efficiency (Figure 3 ). In the beginning of the operation, the reactors were unstable due to the adaptation of sludge used as inoculums in R1, which came from UASB reactor treating swine wastewater, and also from the beginning of R2 and $\mathrm{R} 3$ inoculation with microorganisms dragged with effluents from R1 to R2, then from R2 to R3. Until 100 days, despite fluctuations in removal in R1, R2 and R3, efficiencies remained from 80 to $90 \%$ to the system (R1 + R2 + R3). There was sludge adaptation of R1 and R2 and R3 inoculation, with the accumulation of sludge carried with the effluent of R1.

Then, until 130 days of operation, the removals, in $\mathrm{R} 1$, of $\mathrm{COD}_{\text {total }}$ stabilized at around $70 \%$, and in R2 and R3, between 20 and 30\%. Equilibrium was established between the sludge production and the entrainment of solids with the effluent, such that the removal efficiency of $\mathrm{COD}_{\text {total }}$ in the system $(\mathrm{R} 1+\mathrm{R} 2+\mathrm{R} 3)$, which was around $90 \%$ up to 100 days operation, stabilized at a level of $80 \%$ (Figure 3 ).

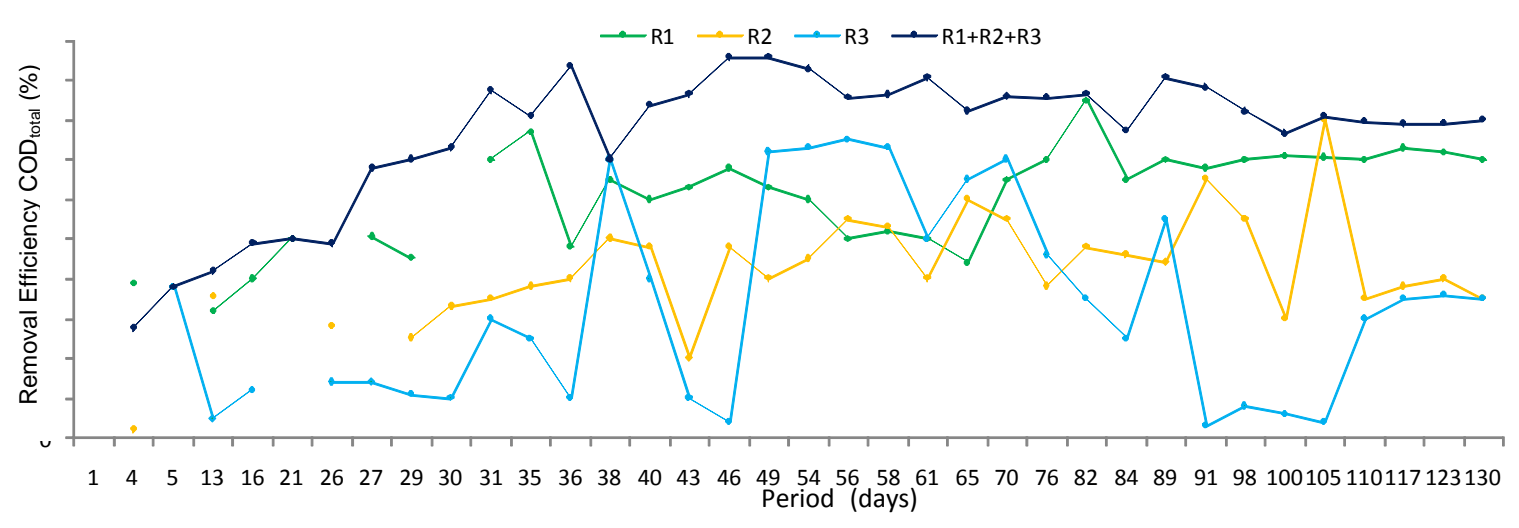

FIGURE 3. Removal efficiency of $\mathrm{COD}_{\text {total }}$ during the start-up of the horizontal anaerobic reactors with sludge blanket (R1) and fixed bed (R2 and R3) and of the treatment system $(\mathrm{R} 1+\mathrm{R} 2+\mathrm{R} 3)$.

Even with these variations, the mean removal efficiency of $\mathrm{COD}_{\text {total }}$ in the set of reactors $(\mathrm{R} 1$ $+\mathrm{R} 2+\mathrm{R} 3$ ) was high, $79 \%$, and with low variation, C.V. of 19\%, with the largest reductions (53\%) in R1 (Table 3).

The mean removal efficiency of COD of $53 \%$ in R1 with VOL of $12.8 \mathrm{~g} \mathrm{COD}_{\text {total }}(\mathrm{L} \mathrm{d})^{-1}$ and HRT of $30 \mathrm{~h}$ was similar to that obtained by BORGES et al. (2009), of 49\%, with VOL of $2.66 \mathrm{~g}$ $\mathrm{COD}_{\text {total }}(\mathrm{L} \mathrm{d})^{-1}$ and HRT of $11.5 \mathrm{~h}$ (Table 1). Still, after 75 days of operation, the reductions of COD stabilized around $70 \%$ in R1 (Figure 3), demonstrating that with the use of sludge blanket in 
horizontal anaerobic reactors it was possible to obtained additions in the removal of dissolved and suspended organic matter with higher VOL and HRT.

Comparing to other settings, SELVAMURUGAN et al. (2010a and b), in UASB hybrid reactors, applied VOL of 9.55 and $14.23 \mathrm{~g} \mathrm{COD}_{\text {total }}(\mathrm{L} \mathrm{d})^{-1}$ with HRT of 18 and $12 \mathrm{~h}$, and achieved removals of COD of 61 and 52\%, respectively. PRADO \& CAMPOS (2008) used the UASB reactor with VOL from 0.14 to $20.29 \mathrm{~g} \mathrm{COD}_{\text {total }}(\mathrm{L} \mathrm{d})^{-1}$ and HRT from 8.0 to $69.7 \mathrm{~h}$, and observed removals of COD from 33 to 93\%. Thus, for similar VOL, in horizontal anaerobic sludge blanket reactor $(\mathrm{R} 1)$, with the application of higher HRT, it could achieve similar performance to the UASB reactor for the removal of COD.

In other research with UASB reactors, similar (OSÓRIO, 1994 quoted by BELLOMENDOZA \& CASTILLO-RIVERA, 1998) and higher (BELLO-MENDOZA \& CASTILLORIVERA, 1998; SILVA \& CAMPOS, 2005) removals were obtained, however applying lower VOL. Only YSSPERT (1984) and VIÑAS et al. (1998) quoted by BELLO-MENDOZA \& CASTILLO-RIVERA (1998) obtained higher removals of COD with higher VOL (Table 1), possibly due to the lower COD of the affluent.

In vertical anaerobic fixed bed reactors, COD removals from 50 to $70 \%$ were achieved in several studies (Table 1), but with lower VOL, of 0.43 to $4.89 \mathrm{~g} \mathrm{COD}_{\text {total }}(\mathrm{L} \mathrm{d})^{-1}$, and HRT from 10 to $122 \mathrm{~h}$, confirming the ability of the horizontal anaerobic reactor to accommodate high VOL with good COD removals.

BRUNO \& OLIVEIRA (2008), using a UASB reactor in two stages subjected to HRT of $96 \mathrm{~h}$ with VOL of $5.8 \mathrm{~g} \mathrm{COD}_{\text {total }}(\mathrm{L} \mathrm{d})^{-1}$, obtained mean removal efficiency of $\mathrm{COD}_{\text {total }}$ of $66 \%$ and verified crash after 30 days operation. They increased HRT to 148 and $120 \mathrm{~h}$ and decreased the VOL to 3.6 and $3.0 \mathrm{~g} \mathrm{COD}_{\text {total }}(\mathrm{L} \mathrm{d})^{-1}$, and so they maintained the reactors stable with a mean efficiency of COD removal of 98 and $96 \%$ (Table 1), respectively, until 125 days of operation. For the set of reactors $(\mathrm{R} 1+\mathrm{R} 2+\mathrm{R} 3)$ with $\mathrm{HRT}$ of $90 \mathrm{~h}$ and higher VOL, stable removals were maintained at around $80 \%$ up to 130 days of operation (Figure 3 ).

TABLE 3. Mean values and coefficients of variation (C.V. in \%) of removal efficiencies (\%) of $\mathrm{COD}_{\text {total }}$ CODdiss, total (TSS) and volatile (VSS) suspended solids, total phenols (TP) obtained during the start-up of the horizontal anaerobic reactors with sludge blanket (R1) and fixed bed (R2 and R3) and of the treatment system (R1+R2+R3).

\begin{tabular}{ccccccccc}
\hline Parameters & R1 & C.V. & R2 & C.V. & R3 & C.V. & R1+R2+R3 & C.V. \\
\hline COD $_{\text {total }}$ & 53 & 37 & 35 & 59 & 36 & 70 & 79 & 19 \\
COD $_{\text {diss }}$ & 49 & 34 & 36 & 69 & 57 & 36 & 78 & 24 \\
TSS & 57 & 37 & 24 & 250 & 13 & 335 & 79 & 11 \\
VSS & 61 & 39 & 44 & 115 & 6 & 336 & 81 & 33 \\
TP & 49 & 41 & 30 & 51 & 19 & 44 & 52 & 35 \\
\hline
\end{tabular}

The use of horizontal anaerobic reactors in series, with sludge blanket and fixed bed, conferred the ability to resist shock of organic loadings and tolerance to changes in the characteristics of the substrate, by virtue of keeping a high concentration of active biomass in the sludge blanket of R1 and adhered to or retained in the interstices of the half supporter in R2 and R3, even subjected to high VOL for the start-up. The reactors R2 and R3 absorbed performance oscillations of R1, as happened on several occasions when the $\mathrm{COD}_{\text {total }}$ of the $\mathrm{R} 1$ affluent increased and, consequently, the removal efficiency decreased. In these situations, removals in R2 and R3 increased and the system (R1 + R2 + R3) efficiency remained high and stable (Figures 2 and 3).

The mean values of total alkalinity (TA) in the affluent were $1,494 \mathrm{mg} \mathrm{L}^{-1}$ and increased to 2052, 2799 and $2493 \mathrm{mg} \mathrm{L}^{-1}$ in the effluents of R1, R2 and R3, respectively, indicating that there was buffering capacity to maintain the mean values of $\mathrm{pH}$ from 7.5 to 7.9 in the effluents (Table 2), 
suitable for microbial activity of anaerobic decomposition of organic matter in the affluent and conversion to methane.

The concentrations of total alkalinity in the effluents of R2 and R3 increased and remained from 25 up to 125 days of operation, confirming the start-up of the set of horizontal anaerobic reactors. From 125 to 130 days of operation, the values decreased (Figure 4) due to the reduction in the affluent and the pronounced decrease in temperature associated with the output of solids in the effluent due to the stabilization between the production and loss of sludge in the reactors.

The mean values of concentration of total volatile acids (TVA) were $2,205 \mathrm{mg} \mathrm{L}^{-1}$ in the affluent and decreased for 1269; 376 and $168 \mathrm{mg} \mathrm{L}^{-1}$ in the effluents of R1, R2 and R3 (Table 2), indicating the activity of anaerobic microorganisms consuming the volatile fatty acids (Figure 5), which also confirms the start-up of the reactors during the studied period. TVA values recommended by GERARDI (2003) are in the range from 50 to $500 \mathrm{mg} \mathrm{L}^{-1}$, so that there is stability in methanogenic anaerobic process. Thus, the horizontal anaerobic fixed bed reactors (R2 and R3) during start-up reached this condition because of lower VOL applied (Table 1). In the effluent of R1, there were higher values and fluctuations of concentrations of TVA (Figure 5), indicating a higher hydrolytic and acidogenic activity in this reactor than in R2 and R3.

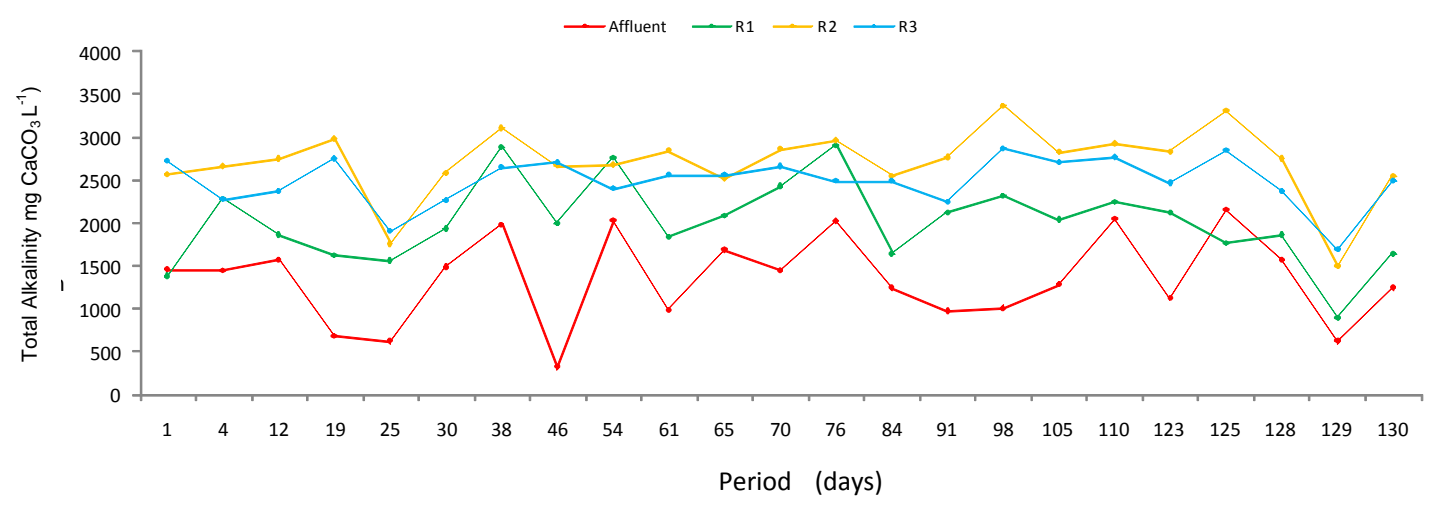

FIGURE 4. Total alkalinity in the affluent and effluents of the horizontal anaerobic reactors with sludge blanket (R1) and fixed bed (R2 and R3) during the start-up.

BRUNO \& OLIVEIRA (2008) obtained mean values of the TVA in the effluent of the treatment system of $1,840 \mathrm{mg} \mathrm{L}^{-1}$ with HRT of $96 \mathrm{~h}$. This value was limiting for the anaerobic process leading to the collapse of reactors and involving the exchange of inoculum and increase of the values of HRT to 148 and $124 \mathrm{~h}$ in the following tests, when it was observed a decrease in the values of TVA to less than $100 \mathrm{mg} \mathrm{L}^{-1}$, making the process stable. PRADO \& CAMPOS (2008), BORGES et al. (2009) and FIA et al. (2010a and b) also managed to maintain the concentration of TVA below $500 \mathrm{mg} \mathrm{L}^{-1}$. When TVA values were higher, a decrease of the removal efficiency of COD to less than $60 \%$ occurred (FIA et al. 2010a, b, c, d) (Table 1). In R1, with TVA values up to $2,000 \mathrm{mg} \mathrm{L}^{-1}$ at 25; 70 and 105 days of operation (Figure 5), there was no crash, showing resistance to high loadings of volatile fatty acids of horizontal anaerobic reactors installed in series. 


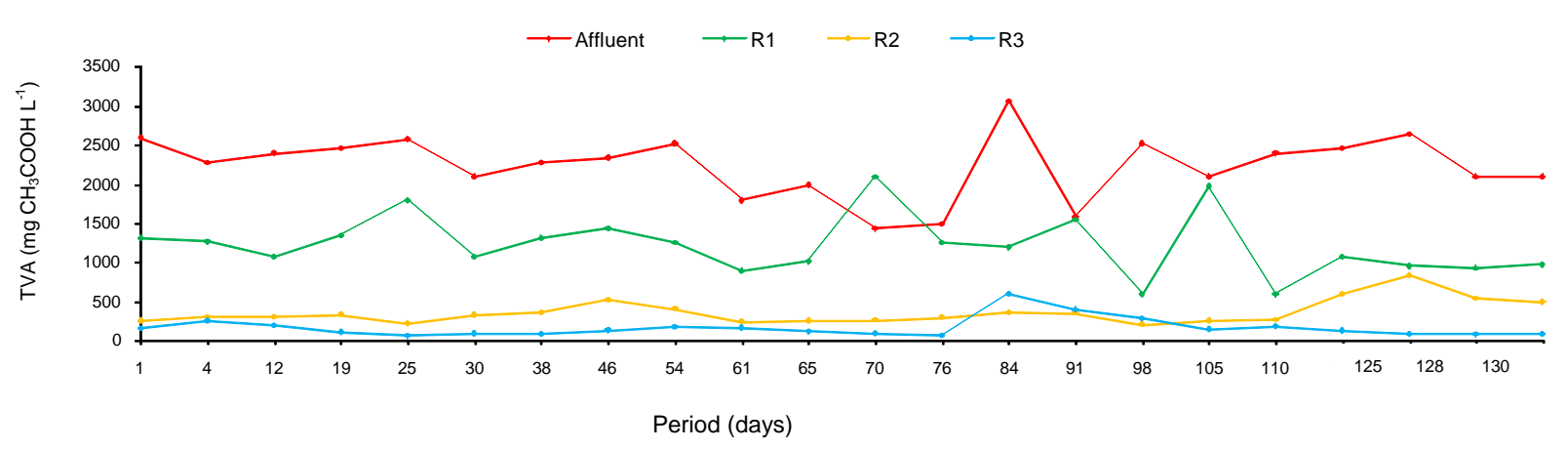

FIGURE 5. Concentration of total volatile acids (TVA) in the affluent and effluents of the horizontal anaerobic reactors with sludge blanket (R1) and fixed bed (R2 and R3) during the start-up.

The concentrations of total phenols (TP) decreased from the affluent to the effluent of reactors $\mathrm{R} 1, \mathrm{R} 2$ and R3 and were, on average, 105; 47; 38 and $44 \mathrm{mg} \mathrm{L}^{-1}$, respectively. As can be seen in Table 2, there was a mean increase of $16 \%$ on the phenol concentration in the effluent of R3 with respect to R2. This fact was correlated to the degradation of the half supporter present in the reactor (coconut fiber), which also changed the color of the effluent of R3 with respect to effluents of R1 and R2. The TP concentration in the affluent was higher than that quoted by BRUNO \& OLIVEIRA (2008), BORGES et al. (2009) and FIA et al. (2010a, b, c and d) and only lower than the maximum values verified by PRADO \& CAMPOS (2008) (Table 1), indicating that the simulated wastewater showed TP concentrations similar to those from the coffee processing by wet method.

The removal efficiencies of TP were 49; 30; 19 and 52\% in R1, R2, R3 and R1+R2+R3, respectively (Table 3). The phenols, despite being toxic compounds, were not limiting for the activity of anaerobic microorganisms present in the biomass of reactors. Comparing with removals listed in Table 1, only BRUNO \& OLIVEIRA (2008), PRADO \& CAMPOS (2008) and FIA et al. (2010a and b) achieved higher efficiencies, however they applied lower phenols loadings, which also confirms the resistance to the presence of toxic compounds of horizontal anaerobic reactors.

The highest mean values of the percentage of methane in the biogas were $76 \%$ and occurred in R1 and R2 (Table 4). There was a decrease to $70 \%$ of methane in the biogas R3, due to the lower VOL and greater amount of recalcitrant organic matter caused by the removal of the fraction of easy decomposition of R1 and R2. PRADO \& CAMPOS (2008) and SELVAMURUGAN et al. (2010a and b) found maximum values of 61 and $68 \%$ of methane in the biogas, respectively, and BRUNO \& OLIVEIRA (2008) found mean values from 69 to $89 \%$, but with lower VOL (Table 1) than those applied in R1. Thus, the horizontal anaerobic reactors, both with sludge blanket and with fixed bed, were able to convert the organic matter to biogas, under VOL higher or similar to those applied in the UASB reactors from the cited authors, maintaining high quality, i.e., with methane percentages above $70 \%$.

The largest production volume of methane occurred in $\mathrm{R} 1$ and in the treatment system composed by the reactors $\mathrm{R} 1+\mathrm{R} 2+\mathrm{R} 3$ reaching a mean value of $1.707 \mathrm{~L} \mathrm{CH}_{4}$ ( $\mathrm{L}$ reactor $\left.\mathrm{d}\right)^{-1}$ (Table 4). It was not possible to obtain data from biogas production in $\mathrm{R} 2$ and $\mathrm{R} 3$ during the first 63 days of operation. The variations in volumetric production of methane (Figure 6), also confirmed the start-up of R1 after 25 days of operation, with stable values around $1.5 \mathrm{~L} \mathrm{CH}_{4}$ ( $\mathrm{L}$ reactor d) ${ }^{-1}$, until 80 days, when a shock of organic loading occurred (Figure 2), the COD of the affluent increased to $31,217 \mathrm{mg} \mathrm{L}^{-1}$. This disturbance caused oscillations until the 100 days of operation. After this period, the methane production returned to the previous stable values, such that the mean for 130 days of operation was $1.459 \mathrm{~L} \mathrm{CH} 4$ ( $(\mathrm{L} \text { reactor } \mathrm{d})^{-1}$ with low coefficient of variation of $20 \%$ (Table 4). 
From the results presented by PRADO \& CAMPOS (2008) and PRADO et al. (2010), the maximum values of measurements of volumetric production of biogas were from 1.44 to $1.56 \mathrm{~L}$ $(\mathrm{L} \text { reactor } \mathrm{d})^{-1}$, with a methane content of 50 to $60 \%$, which can be considered lower than the mean value of volumetric production of methane of R1, considering that the authors applied VOL of up to $20.3 \mathrm{~g} \mathrm{COD}(\mathrm{L} \mathrm{d})^{-1}$. BRUNO \& OLIVEIRA (2008) observed volumetric productions of 0.48 and $0.45 \mathrm{~L} \mathrm{CH}_{4}(\mathrm{~L} \text { reactor d })^{-1}$ with VOL of 3.8 and $3.0 \mathrm{~g} \mathrm{COD}_{\text {total }}(\mathrm{L} \mathrm{d})^{-1}$, respectively, which can be considered proportionally similar, due to the application of VOL of $12.8 \mathrm{~g} \mathrm{COD}_{\text {total }}(\mathrm{L} \mathrm{d})^{-1}$ in $\mathrm{R} 1$.

TABLE 4. Mean values and coefficients of variation (C.V. in \%) of the percentage of methane in the biogas and methane volumetric and specific productions during the start-up of the horizontal anaerobic reactors with sludge blanket (R1) and fixed bed (R2 and R3), and of the treatment system $(\mathrm{R} 1+\mathrm{R} 2+\mathrm{R} 3)$.

\begin{tabular}{ccccccc}
\hline $\begin{array}{c}\text { Horizontal } \\
\text { Anaerobic } \\
\text { Reactors }\end{array}$ & $\mathrm{CH}_{4}$ & C.V. & $\begin{array}{c}\text { Methane Volumetric } \\
\text { Production }\end{array}$ & \multicolumn{2}{c}{ C.V. Methane Specific Production } & C.V. \\
\cline { 2 - 6 } & $(\%)$ & $(\%)$ & $\left(\mathrm{L} \mathrm{CH}_{4}(\mathrm{~L} \text { reactor d })^{-1}\right)$ & $(\%)$ & $\left(\mathrm{LCH}_{4}(\mathrm{~g} \text { CODremoved })^{-1}\right)$ & $(\%)$ \\
\hline $\mathrm{R} 1$ & 76 & 9 & 1.459 & 20 & 0.195 & 40 \\
$\mathrm{R} 2$ & 76 & 7 & 0.347 & 16 & 0.212 & 18 \\
$\mathrm{R} 3$ & 70 & 6 & 0.136 & 36 & 0.157 & 95 \\
$\mathrm{R} 1+\mathrm{R} 2+\mathrm{R} 3$ & - & - & 1.707 & 28 & 0.172 & 63 \\
\hline
\end{tabular}

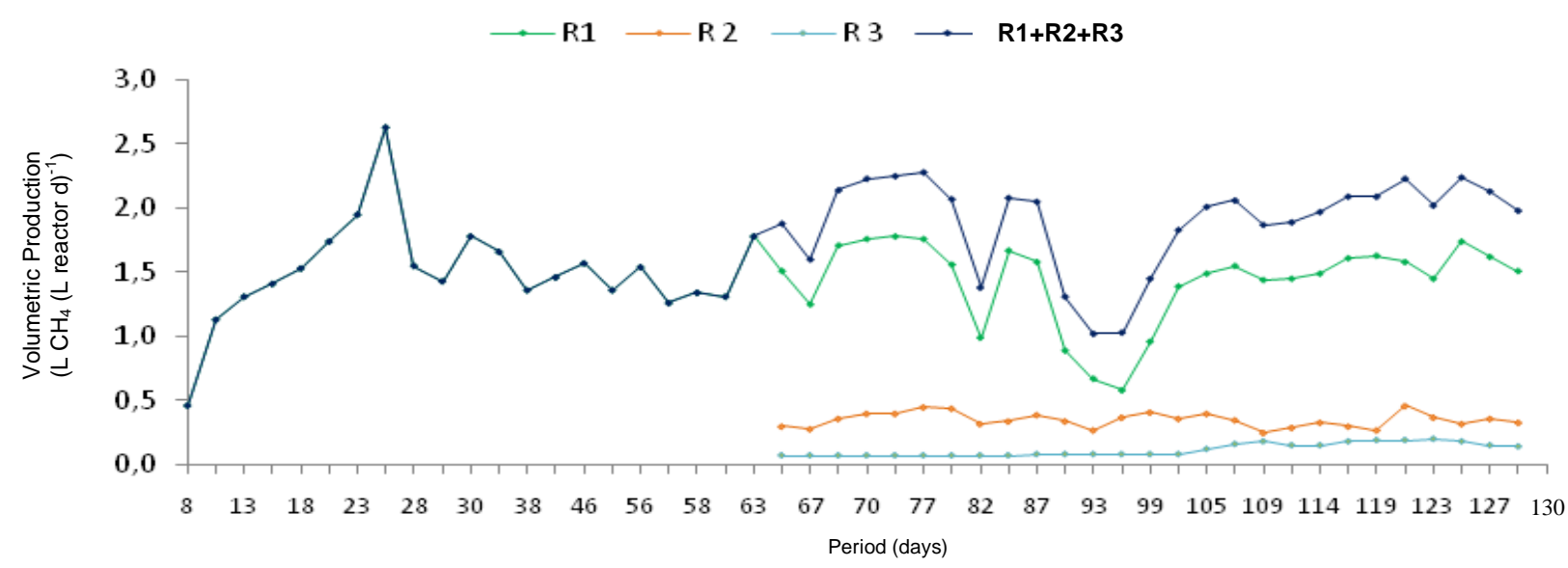

FIGURE 6. Methane volumetric production during the start-up of the horizontal anaerobic reactors with sludge blanket $(\mathrm{R} 1)$ and fixed bed (R2 and $\mathrm{R} 3)$, and of the treatment system $(\mathrm{R} 1+\mathrm{R} 2+\mathrm{R} 3)$.

In R2 and R3 there was a delay in the production of methane due to lack of inoculum in the means of transport. The formation of sludge, by retention in the interstices or adhesion to the half supporter, occurred with microorganisms entrained with the effluent of R1. Thus, only after 63 days of operation it was possible to obtain continuous measurements of biogas. In R2, the accumulated sludge was sufficient to maintain mean volumetric production of $0.347 \mathrm{~L} \mathrm{CH}_{4}$ ( $\mathrm{L}$ reactor d) ${ }^{-1}$ stable with a C.V. of 16\% (Table 4 and Figure 6). In R3, methane production has increased and stabilized at 103 days of the operation (Figure 6), such that for the mean value of $0.136 \mathrm{~L} \mathrm{CH}_{4}$ ( $\mathrm{L}$ reactor d) ${ }^{-1}$ variation was higher, with C.V. of $36 \%$ (Table 3), indicating that there was a need for longer operation time to obtain the proper inoculation.

With respect to the conversions of organic matter to methane, they were higher and more stable in R1 and R2, with mean values of specific methane production of 0.195 and $0.212 \mathrm{~L} \mathrm{CH}_{4}$

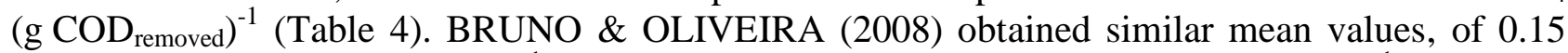
and $0.19 \mathrm{~L} \mathrm{CH}_{4}\left(\mathrm{~g} \mathrm{COD}_{\text {removed }}\right)^{-1}$, with lower VOL, of 3.8 and $3.0 \mathrm{~g} \mathrm{COD}_{\text {total }}(\mathrm{L} \mathrm{d})^{-1}$. From the 
results presented by SELVAMURUGAN et al. (2010a), higher mean values were obtained, of 0.26 and $0.23 \mathrm{~L} \mathrm{CH}_{4}\left(\mathrm{~g} \mathrm{COD}_{\text {removed }}\right)^{-1}$, with similar VOL, of 9.5 and $14.2 \mathrm{~g} \mathrm{COD}_{\text {total }}(\mathrm{L} \mathrm{d})^{-1}$ (Table 1).

Thus, it was observed that, with the horizontal anaerobic reactors, it was possible to obtain methane production similar or higher to those obtained in UASB reactors in one and two stages, and hybrids, with conversions of organic matter, slightly lower than those observed in hybrid UASB reactor, in similar VOL conditions. However, the R1 was fed with wastewater with higher mean values of COD, except when compared with those used by BRUNO \& OLIVEIRA (2008).

\section{CONCLUSIONS}

The start-up of the horizontal anaerobic sludge blanket reactor occurred after 30 days of operation due to the use of active anaerobic sludge as inoculum. The strategy for inoculation of the second and third anaerobic fixed bed reactors with micro-organisms contained in the effluents from the first and second reactors, respectively, has succeeded.

With the treatment system composed of horizontal anaerobic reactors with sludge blanket and fixed bed, installed in series, it was possible to treat wastewater from coffee fruits processing by wet method with removal efficiencies of COD and VSS around $80 \%$ and methane volumetric and specific productions over $1.50 \mathrm{~L}$ ( $\mathrm{L}$ reactor $\mathrm{d})^{-1}$ and $0.16 \mathrm{~L}\left(\mathrm{~g} \mathrm{COD}_{\text {total }}\right.$ removed), respectively, in stable condition, applying VOL from 8.9 to $25.0 \mathrm{~kg} \mathrm{COD}_{\text {total }}\left(\mathrm{m}^{3} \mathrm{~d}\right)^{-1}$ with HRT of $90 \mathrm{~h}$.

The highest values of removal efficiencies of $\mathrm{COD}_{\text {total }}, \mathrm{SSV}$ and total phenols, and methane production occurred in the first horizontal anaerobic reactor, in which the sludge blanket was used. The second and third horizontal anaerobic fixed bed reactors were important to increase and stabilize these values and to accommodate shocks of organic loading.

The use of fixed bed with coconut fibers changed the color and increased the concentration of phenols in the effluent due to decomposition of less stable fractions of the half supporter.

\section{ACKNOWLEDG EMENTS}

To CAPES, for the scholarship and financial support.

\section{REFERENCES}

AMORIM, A.K.B.; ZAIAT, M.; FORESTI, E. Performance and stability of an anaerobic fixed bed reactor subjected to progressive increasing concentrations of influent organic matter and organic shock loads. Journal of Environmental Management, Galway, v.76, p. 319-325, 2005.

APHA, AWWA, WPCF. Standart methods for the examination of water and wastewater. 18 th. Washington, 2005. $1268 \mathrm{p}$.

BARBOZA, M.G. Efeitos da temperatura e da velocidade superficial em sistema anaeróbio de duas fases tratando esgoto sanitário sintético em reatores horizontais com células imobilizadas. 2002. 162 f. Tese (Doutorado em Hidráulica e Saneamento) - Universidade de São Paulo, Escola de Engenharia de São Carlos, São Carlos, 2002.

BELLO-MENDOZA, R.; CASTILLO-RIVERA, M.F. Start-up of an anaerobic hybrid (UASB/filter) reactor treating wastewater from a coffee processing plant. Anaerobe, London, v.4, n.5, p.219-225, 1998.

BENIS, S.G.; BORJA, R.; MONEMIAN, S.; GOODARZI, V. Anaerobic treatment of synthetic medium-strength wastewater using a multistage biofilm reactor. Bioresource Technology, Essex, v.100, n.5, p.1.741-1.745, 2009.

BORGES, A.C.; PEREIRA, P.A.; MATOS, A.T. Partida de um reator anaeróbio horizontal para tratamento de efluentes do processamento dos frutos do cafeeiro. Engenharia Agrícola, Jaboticabal, v. 29, n.4, p.661-669, 2009. 
BRUNO, M.; OLIVEIRA, R.A. de. Tratamento anaeróbio de águas residuárias do beneficiamento de café por via úmida em reatores UASB. Engenharia Agrícola, Jaboticabal, v.28, n.2, p.364-377, 2008.

COLIN, X.; FARINET, J.L.; ROJAS, O.; ALAZARD, D. Anaerobic treatment of cassava starch extraction wastewater using a horizontal-flow filter with bamboo as support. Bioresource Technology, Essex, v.98, p.1602-1607, 2007.

CONAB. COMPANHIA NACIONAL DE ABASTECIMENTO. Cafés do Brasil, safra 2012, segundo levantamento. Disponível em < http://www.conab.gov.br/OlalaCMS/uploads/arquivos/ 12_05_10_08_56_04_boletim_cafe_-_maio_2012.pdf >. Acessado em: 30 ago. 2012.

DILALLO, R.; ALBERTSON, O. E. Volatile acids by direct titration. Journal of Water Pollution Control Federation, Alexandria, v.33, n.4, p.356-365, 1961.

FIA, F.R.L.; BORGES, A.C.; MATOS, A.T.; DUARTE, I.C.S.; FIA, R.; CAMPOS, L.C. Development of biofilm in anaerobic reactors treating wastewater from coffee grain processing. Revista Brasileira de Engenharia Agrícola e Ambiental, Campina Grande, v.14, n.2, p.210-217, 2010a.

FIA, F.R.L.; MATOS, A.T. de; BORGES, A.C.; MOREIRA, D.A.; FIA, R.; JUNIOR, V.E. Remoção de compostos fenólicos em reatores anaeróbios de leito fixo com diferentes materiais suporte. Revista Brasileira de Engenharia Agrícola Ambiental, Campina Grande, v.14, n.10, p.1079-1086, 2010b.

FIA, R; MATOS, A.T. de; MATOS, M.P. de; ABREU, E.C.; FIA, F.R.L. Tratamento das águas residuárias do processamento de frutos do cafeeiro em filtro anaeróbio seguido por sistema alagado construído: I - remoção de matéria orgânica. Engenharia Agrícola, Jaboticabal, v.30, n.6, p.11911202, 2010c.

FIA, R.; MATOS, A.T. de; MATOS, M.P. de; ABREU, E.C.; FIA, F.R.L. Tratamento das águas residuárias do processamento de frutos do cafeeiro em filtro anaeróbio seguido por sistema alagado construído: I - remoção de nutrientes e compostos fenólicos. Engenharia Agrícola, Jaboticabal, v.30, n.6, p.1203-1213, 2010d.

GERARDI, M.H. The microbiology of anaerobic digesters. Chichester: John Wiley, 2003. 165 p.

LEITE, C.A.M.; SILVA, O.M. da. Demanda de cafés especiais. In: ZAMBOLIM, L. Café: produtividade, qualidade e sustentabilidade. Viçosa: Imprensa Universitária,UFV, 2000. p.50-74

LUIZ, F.R. Desempenho de reatores anaeróbios de leito fixo no tratamento de águas residuárias da lavagem e descascamento/despolpa dos frutos do cafeeiro. 2007. 132 f. Dissertação (Mestrado em Engenharia Agrícola) - Universidade Federal de Viçosa, Viçosa, 2007.

MATOS, A.T.; LO MÔNACO, P.A. Tratamento e aproveitamento agrícola de resíduos sólidos e líquidos da lavagem e despolpa dos frutos do cafeeiro. Viçosa: DEA/UFV, 2003. (Boletim Técnico 7).

PRADO, M.A.C.; CAMPOS, C. M. M. Produção de biogás no tratamento dos efluentes líquidos do processamento de Coffea arábica L. em reator anaeróbico para o potencial aproveitamento na secagem do café. Ciência e Agrotecnologia, Lavras, v.32, n.3, p.938-947, 2008.

PRADO, M. A. C.; CAMPOS, C. M. M.; SILVA, J. F. da. Estudo da variação da concentração de metano no biogás produzido a partir das águas residuárias do café. Ciência e Agrotecnologia. Lavras, v.34, n.2, p.475-484, 2010.

RODGERS, M.; PAOR, D de; CLIFFORD, D. Dairy wastewater treatment using a horizontal flow biofilm system. Journal of Environmental Management, Galway, v.86, n.1, p.114-120, 2008.

SANTOS, A.C. dos; OLIVEIRA, R.A. de. Tratatamento de águas residuárias de suinocultura em reatores anaeróbios horizontais seguidos de reator aeróbio em bateladas sequencial. Engenharia Agrícola, Jaboticabal, v.31, n.4, p.781-794, 2011. 
SELVAMURUGAN, M.; DORAISAMY, P.; MAHESWARI, M. An integrated treatment system for coffee processing wastewater using anaerobic and aerobic process. Ecological Engineering, Oxford, v.36, p.1686-1690, 2010a.

SELVAMURUGAN, M.; DORAISAMY, P.; MAHESWARI, M., NANDAKUMAR, N.B. High rate anaerobic treatment of coffee processing wastewater using upflow anaerobic hybrid reactor. Iranian Journal Environmental Health Science and Engineering, Tehran, v.7, p.129-136, $2010 \mathrm{~b}$.

SHAHIDI, F.; NACZK, M. Food phenolics: sources, chemistry, effects and aplications. Basel: Technomic Publishing, 1995. 331 p.

SILVA, B.A.; CAMPOS, C.M.M. Tratamento anaeróbio de efluentes líquidos gerados no beneficiamento úmido do café. In. CONGRESSO BRASILEIRO DE ENGENHARIA AGRÍCOLA, 34., 2005, Canoas. Anais... Jaboticabal: Associação Brasileira de Engenharia Agrícola, 2005. 1 CDROM.

SILVA, J.L.; CEZAR, V.R.S.; BARBOZA, M.G. Avaliação preliminar da tratabilidade da manipueira através do reator anaeróbio horizontal com chicanas - RAHC. In: SIMPÓSIO LUSOBRASILEIRO DE ENGENHARIA SANITÁRIA E AMBIENTAL, 13., 2008, Belém. Anais... Rio de Janeiro: Associação Brasileira de Engenharia Sanitária e Ambiental, 2008. 1 CD-ROM.

UNESP. UNIVERSIDADE ESTADUAL PAULISTA. Faculdade de Ciências Agrárias e Veterinárias. Departamento de Ciências Exatas. Estação agroclimatológica: valores médios de período de 1971 a 2000. Disponível em: <www.fcav.unesp.br/estação〉. Acesso em: 10 jun. 2010.

ZAIAT, M.; CABRAL, A.K.A.; FORESTI, E. Reator anaeróbio horizontal de leito fixo para tartar águas residuárias: concepção e avaliação preliminar de desempenho. Revista Brasileira de Engenharia - Caderno de Engenharia Química, São Carlos, v.11, n.2, p.33-42, 1994. 